\title{
PENGUATAN PROFESIONALISME GURU PENDIDIKAN AGAMA ISLAM BERBASIS NILAI-NILAI PROFETIK
}

\author{
Moh. Faizin 1 \\ IUIN Sunan Ampel Surabaya
}

\begin{abstract}
ABSTRAK
Melalui UU No.14 Tahun 2005 tentang guru dan dosen, profesi guru mendapatkan tempat yang sejajar dengan dengar profesi lainnya Namun sebenarnya ada hal yang mendasar yang terkadang tak disadari, yaitu nilai profetik profesi guru. Oleh sebab itu, penelitian ini berupaya untuk mendeskripsikan dan menganalisis implementasi penguatan profesionalisme guru Pendidikan Agama Islam (PAI) berbasis nilai-nilai profetik pada mahasiswa Prodi PAI FTK UIN Sunan Ampel Surabaya, berikut problematika dan dampaknya. Artikel ini merupakan penelitian kualitatif dengan pendekatan rasionalistas dan fenomenologis. Penelitian ini menemukan bahwa, dengan mengimplementasikan penguatan profesionalisme melalui nilai-nilai profetik menjadikan tujuan pembelajaran lebih mudah untuk dicapai dan kualitas pendidikan lebih terjaga. Dalam proses implementasinya muncul beberapa problem yang menjadi penghambat, di antaranya: latar belakang keilmuan dosen, pemahaman mahasiswa terhadap desain pembelajaran, dan sarana pendukung. Namun demikian, ada dampak positif dari implementasi program tersebut di antaranya: menciptakan suasana pembelajaran yang menyenangkan, mengembangkan aspek kebudayaan peserta didik, membentuk karakter calon guru ideal, aktualisasi pendidikan multicultural, dan mahasiswa terlatih melaksanakan pembelajaran integratif. Agar lebih optimal, penting untuk selalu menanamkan nilai-nilai humanisme, seperti toleransi, menhargai hak-hak orang lain, dan menghargai keberagaman. Lebih dari itu, pembentukan kepribadian seorang calon guru harus menjadi agenda yang benar-benar dipersiapkan oleh lembaga seperti dilakukannya pembinaan kepribadian.

Kata Kunci: Profesionalisme, Guru, Pendidikan Agama Islam, Nilai Profetik.

\section{ABSTRACT}

Through Law Number 14 of 2005 concerning teachers and lecturers, the teaching profession has an equal place with other professions. However, there is actually a fundamental thing that is sometimes not realized, namely the prophetic value of the teaching profession. Therefore, this study seeks to describe and analyze the implementation of strengthening the professionalism of Islamic Religious Education (PAI) teachers based on prophetic values for PAl students at the Islamic Education Study Program, UIN Sunan Ampel Surabaya, along with the problems and impacts. This article is a qualitative research with rationalist and phenomenological approaches. This study found that, by implementing strengthening professionalism through prophetic values, learning objectives were easier to achieve and the quality of education was maintained. In the implementation process, several problems emerged that became obstacles, including: the scientific background of the lecturers, students' understanding of learning design, and supporting facilities. However, there are positive impacts from the implementation of the program, including: creating a pleasant learning atmosphere, developing cultural aspects of students, shaping the character of ideal teacher candidates, actualizing multicultural education, and trained students in implementing integrative learning. To be more optimal, it is important to always instill humanist values, such as tolerance, respect for the rights of others, and respect for diversity. More than that, the formation of the personality of a prospective teacher must be an agenda that is really prepared by the institution such as personality development.

Keywords: Professionalism, Teachers, Islamic Religious Education, Prophetic Values.
\end{abstract}

\section{A. Pendahuluan}

Pendidikan Islam menjadi filter dan tameng bagi adanya kemajuan teknologi khususnya teknologi komunikasi dan informasi yang dikuasai barat yang menjadikan kekalahan beruntun secara sosial, politik, ekonomi, dan budaya, komunitas muslim merasa kelimpungan dengan reaksi yang beragam. Diakui bahwa hal ini disebabkan 
karena masih ada beberapa hambatan dalam pendidikan agama Islam. Karena terjadinya pengadopsian pendidikan barat untuk mengembangkan pendidikan agama Islam. ${ }^{1}$

Mengamati pendidikan agama Islam di Indonesia dari masa ke masa, tergambar jelas bahwa pendidikan agama Islam merupakan bagian yang terpisah dari sistem pendidikan nasional. ${ }^{2}$ Bahkan saat ini pendidikan Islam di Indonesia sedang menghadapi berbagai persoalan dan hambatan dalam berbagai aspek, terutama masalah orientasi pendidikan itu sendiri, dengan kata lain masih belum jelasnya konsep pendidikan yang dibawa serta bagaimana implementasi yang berbentuk pembelajaran sebagai upaya menciptakan manusia yang mandiri dan profesional. Mengingat bahwa pendidikan agama Islam merupakan kebutuhan dasar bagi setiap muslim, maka pendidikan agama Islam harus selalu ditumbuh kembangkan secara sistematis oleh setiap umat Islam dimanapun.. ${ }^{3}$ Kurangnya jam pembelajaran pendidikan agama Islam dalam pendidikan umum misalnya yang hanya 3 jam setiap minggu, maka perlu adanya strategi untuk memberikan bekal tentang pendidikan agama di pendidikan umum. Strategi dalam sistem pembelajarannya, metodenya, maupun dalam hal konsep pembelajarannya. Seperti penggunaan pendidikan profetik, yaitu dengan proses pengetahuan dan nilai yang bertujuan untuk mendekatkandiri kepada Tuhan. ${ }^{4}$

Berbicara tentang guru sebenarnya merupakan hal yang klise. Namun, selama dunia masih ada, maka pembicaraan tentang guru sepertinya tak akan pernah usai. Guru dan problematikannya tetap akan memiliki porsi penting dalam kehidupan karena guru adalah penjaga peradaban. Seperti yang sudah diketahui bersama bahwa sejak tahun 2005 pemerintah telah mengeluarkan UU No.14 Tahun 2005 Tentang Guru dan Dosen. Dengan legitimasi itu profesi guru seakan naik kelas. Guru mendapatkan tempat yang sejajar dengan dengar profesi lainnya. Hal itu nampak dari antusias para generasi muda untuk kuliah di bidang keguruan. ${ }^{5}$

Namun sebenarnya ada hal yang mendasar tentang profesi guru yang terkadang tak disadari oleh guru itu sendiri, yaitu nilai profetik profesi guru. Istilah profetik berasal dari bahasa Inggris prophet yang berarti Nabi. Dalam bahasa Arab, kata prophet disebut nubuwwah yang merujuk pada pada kenabian dan gagasan perilaku Nabi.

\footnotetext{
${ }^{1}$ Abdul Majid dan Dian Andayani, Pendidikan Agama Islam Berbasis Kompetensi (Bandung: Remaja Rosda Karya, 2004 ), 74.

2 Moh. Sakir, “Pendidikan Islam dalam Sistem Pendidikan Nasional”, Cendekia, Vol. 12 No. 1 (Juni 2014).

${ }^{3}$ Kuntowijoyo, Paradigma Islam Interpretasi Untuk Aksi (Bandung: Mizan, 1998), 289.

${ }^{4}$ Abd. Rouf, "Potret Pendidikan Agama Islam di Sekolah Umum", Jurnal Pendidikan Agama Islam (Journal of Islamic Education Studies), Vol.3 No.1 (2016): 187-206.

${ }^{5}$ Kuntowijoyo, Islam Sebagai Ilmu: Epistemologi, Metodologi, dan Etika (Yogyakarta: Tiara Wacana, 2006$), 87$. 
Dengan demikian, maka profesi guru merupakan profesi yang sangat mulia karena membawa semangat kenabian. Profetik mengarah pada tiga aspek, yaitu humanisasi atau menyuruh kepada kebaikan (amar ma'ruf), liberasi atau mencegah kejahatan(nahi munkar), dan transendensi atau beriman kepada Tuhan (tu' minu billah). Tiga tersebut merupakan bagian dari tugas dan kewajiban guru dalam mendidik para siswanya. ${ }^{6}$

Dalam mendidik, tentu guru selalu akan menanamkan nilai-nilai humanisme, seperti toleransi, menhargai hak-hak orang lain, dan menghargai keberagaman. Jika semangat ini disadari betul oleh guru untuk kemudian diterapkan pada siswa, maka dapat mereduksi bahkan dapat mencegah dehumanisasi pada masa yang akan datang. Sebaliknya, jika tidak maka bukan tidak mungkin generasi mendatang akan mengulangi hal-hal buruk terkait dengan humanisme yang selama ini sudah terjadi akan terulang kembali. Selain humanisasi, guru juga memiliki peran besar dalam liberasi, yaitu mencegah kejahatan. Maraknya kejahatandan gerakan radikal yang terjadi saat ini perlu ditanggapi serius oleh dunia pendidikan, terutama guru.

Yang terakhir adalah transendensi. Guru tak sekadar mengajarkan ilmu-ilmu terapan dan ilmu-ilmu umum, namun lebih jauh lagi, yaitu menjadi mananamkan nilainilai kebertuhanan pada peserta didik. Secara eksplisit hal itu sudah umum dilakukan melalui aktivitas berdoa sebelun dan sesudah pembelajaran. ${ }^{7}$ Namun, perkara kebertuhanan tidak saja tentang berdoa. Lebih dari itu, guru harus mengajak dan menanamkan pada peserta didik untuk memahami betul tentang keberadaan dan kedudukan manusia sebagai hamba Tuhan. Dengan kesadaran itu, maka akan terpancar nilai-nilai ketuhanan pada peserta didik yang tercermin dalam sikap dan perilaku keseharian. Nilai profetik pada profesi guru handaknya menjadi pemicu semangat bagi para guru untuk lebih optimal dalam menjalankan tupoksi meskipun harus diakui bahwa masih banyak persoalan yang membelit para guru, terlebih lagi para guru honorer saat ini. $^{8}$

Ditetapkanya mahasiswa prodi PAI Fakultas Tarbiyah dan Keguruan UIN Sunan Ampel Surabaya sebagai obyek penelitian, karena adanya strategi dan upaya-upaya yang digunakan mereka sebagai calon guru PAl yang dapat menumbuhkan pendidikan keagamaan Islam terhadap peserta didiknya. Berangkat dari hal tersebut, maka penulis berupaya menganalisis penguatan profesionalisme guru pendidikan agama Islam

6 C.P. Sari, H. S. Zainiyati \& R. A. Hana, “Buliding Students' Character Through Prophetic Education at Madrasa", Jurnal Pendidikan Islam, Vol. 6 No. 1 (June 2020).

${ }^{7}$ Musthofa Rembangy, Pendidikan Transformatif Pergulatan Kritis Merumuskan Pendidikan Di Tengah Pusaran Arus Globalisasi (Yogyakarta: TERAS, 2010), 13-15.

8 Lihat, Idris Apandi, Guru Profesional Bukan Guru Abal - Abal (Yogyakarta : Deepublish, 2017). 
berbasis nilai-nilai profetik. Penelitian ini memerlukan pendekatan kualitatif untuk menjamin diperolehnya pemahaman terhadap realitas lapangan yang utuh. Sehubungan dengan hal itu, gabungan antara pendekatan rasionalitas dan fenomenologis sesuai untuk diterapkan. 9 Persoalan pokok dalam penelitian ini adalah mengenai pengembangan penguatan profesionalisme guru PAl berbasis nilai-nilai profetik khususnya pada mahasiswa prodi PAI Fakultas Tarbiyah dan Keguruan UIN Sunan Ampel Surabaya. Penelitian ini berusaha menggambarkan fenomena pada kondisi alamiah secara holistic, kompleks, dinamis, dan bermakna.

\section{B. Nilai Profetik dalam Proses Pendidikan}

Menurut bahasa, “nilai” artinya sifat-sifat (hal-hal) yang penting atau berguna bagi kemanusiaaan. Sedangkan secara istilah nilai adalah esensi yang melekat pada sesuatu yang sangat berarti bagi kehidupan manusia. Nilai adalah realitas abstrak yang merupakan prinsip-prinsip yang menjadi pedoman hidup seseorang. ${ }^{10}$ Nilai tersebut menjadi daya pendorong dalam hidup, yang memberi makna dan pengabsahan pada tindakan seseorang. Nilai mempunyai dua segi intelektual dan emosional, kombinasi kedua dimensi tersebut menentukan sesuatu nilai beserta fungsinya dalam kehidupan. Bila dalam pemberian makna dan pengabsahan terhadap suatu, unsur emosionalnya kecil sekali, sementara unsur intelektualnya lebih dominan, kombinasi tersebut disebut norma/prinsip. Norma-norma/prinsip-prinsip seperti keimanan, keadilan persaudaraan dan sebagainya baru menjadi nilai-nilai apabila dilaksanakan dalam pola tingkah laku dan pola berpikir suatu kelompok. Jadi norma bersifat sedangkan nilai-nilai bersifat khusus dan relatif bagi masing-masing kelompok universal dan absolut,sedangkan nilainilai bersifat khusus dan relatif bagi masing-masing kelompok. ${ }^{11}$

Profetik adalah kenabian atau suatu sifat, prilaku dan ucapan yang ada pada diri Nabi. Bahwasanya Nabi memiliki sifat yang mulia dalam berperilaku maupun berucap. Selain itu Nabi merupakan tokoh pembebas dari segala hal, seperti kekerasan, kebodohan, kemiskinan dll. Dengan perilaku yang dimiliki seorang Nabi, dapat menjadi contoh dalam menumbuhkan prilaku yang sesuai dengan nilai-nilai Islam. Secara definitif, profetik dapat dipahami sebagai seperangkat teori yang tidak hanya mendeskripsikan dan mentransformasikan gejala sosial, dan tidak pula hanya mengubah suatu hal demi perubahan, namun lebih dari itu, diharapkan dapat mengarahkan

\footnotetext{
${ }_{9}^{9}$ Noeng Muhajir, Metodologi Penelitian Kualitatif (Yogyakarta: Rake Sarasin, 2000), 12.

10 Tim Redaksi, Kamus Besar Bahasa Indonesia Pusat Bahasa (Jakarta: PT. Gramedia, 2008), 963.

11 EM. Kaswardi, Pendidikan Nilai Memasuki Tahun 2000 (Jakarta: Gramedia, 2001), 20-22.
} 
perubahan atas dasar cita-cita etik dan profetik. Adapun nilai-nilai profetik itu sendiri meliputi: ${ }^{12}$

Pertama, humanisasi. Dalam bahasa agama, konsep humanisasi adalah terjemahan kreatif dari amar ma"ruf yang makna asalnya menganjurkan menegakkan kebajikan. Dalam bahasa ilmu, secara etimologi, humanisasi berasal dari bahasa latin humanitas yang artinya makhluk manusia, kondisi menjadi manusia. Secara terminologi, humanisasi berarti memanusiakan manusia, menghilangkan kebendaan, ketergantungan, kekerasan dan kebencian dari manusia. ${ }^{13}$ Makna humanisme-teosentris adalah manusia harus memusatkan diri kepada Tuhan, tetapi tujuannya adalah untuk kepentingan manusia sendiri. Maksudnya, keyakinan religius yang berakar pada pandangan teosentris, selalu dikaitkan dengan amal atau perbuatan manusia, keduanya merupakan satu kesatuan yang tidak terpisahkan. Humanisme-teosentris inilah yang merupakan nilai inti (core-value) dari seluruh ajaran Islam. Menurut Ali Syari'ati, dalam khazanah filsafat Barat, dikenal adanya filsafat humanisme yang menyatakan oposisi terhadap filsafat-filsafat keagamaan yang didasari oleh kepercayaan yang serba ghaib dan supranatural serta bertujuan untuk memulihkan martabat manusia. ${ }^{14}$ Ali Syari'ati menambahkan, filsafat humanisme Barat berpandangan bahwa tidak ada dewa-dewa, tidak ada hubungan antara manusia dengan surga serta menitikberatkan kepada alam antroposentris atau untuk menjadikan manusia sebagai batu ujian kebenaran dan kepalsuan serta memakai manusia sebagai kriteria keindahan dan untuk memberikan nilai keindahan pada bagian kehidupan yang meningkatkan kekuatan dan kesenangan manusia. Dengan kata lain, manusia menjadi pusat kebenaran etika, kebijaksanaan dan pengetahuan. Manusia adalah pencipta, pelaksana dan konsumen produk-produk manusia sendiri.

Kedua, liberalisasi. Liberasi adalah bahasa ilmu dari nahi munkar. Jika dalam bahasa agama nahi munkar artinya mencegah dari segala tindak kejahatan yang merusak, memberantas judi, lintah darat, korupsi dan lainnya, maka dalam bahasa ilmu, nahi munkar artinya pembebasan dari kebodohan, kemiskinan dan penindasan. Secara etimologi, liberasi berasal dari bahasa latin liberare yang artinya memerdekakan. Secara istilah, liberasi dapat diartikan dengapembebasan, semuanya dengan konotasi yang memiliki signifikansi sosial. ${ }^{15}$ Liberasi yang dimaksud adalah

\footnotetext{
12 Khoiron Rosyadi, Pendidikan Profetik (Yogyakarta: Pustaka Pelajar, 2004).

${ }^{13}$ Kuntowijoyo, Islam Sebagai Ilmu, 7-8.

${ }^{14}$ Baca, Ali Shariati, Man and Islam (Houston, tx: Free Islamic Lit. Book Distribution Center, 1981).

15 Ibid.
} 
dalam konteks ilmu, yang didasari nilai-nilai luhur transendental. Nilai-nilai liberatif dipahami dan didudukkan dalam konteks ilmu sosial yang memiliki tanggung jawab profetik. Tujuan liberasi adalah pembebasan manusia dari kekejaman pemiskinan struktural, keangkuhan teknologi, pemerasan kelimpahan, dominasi struktur yang menindas dan hegemoni kesadaran palsu. Semangat liberatif ini dicari pada nilai-nilai profetik transendental dari agama yang telah ditransformasikan menjadi ilmu yang obyektif faktual.

Ketiga, transendensi. Kata transendensi berasal dari kata transcendere adalah bahasa Latin yang artinya naik ke atas. Dalam bahasa Inggris berarti to transcend yang artinya menembus, melewati dan melampaui. ${ }^{16}$ Menurut istilah, libersi berarti perjalanan di atas atau di luar. Yang dimaksud transendensi dalam istilah teologis, yaitu bermakna ketuhanan, makhluk-makhluk gaib. Tujuan transendensi adalah untuk menambahkan dimensi transendental dalam kebudayaan, membersihkan diri dari arus hedonisme, materialisme dan budaya yang dekaden. Dimensi transendental adalah bagian sah dari fitrah kemanusiaan sebagai bentuk persentuhan dengan kebesaran Tuhan. Jika banyak pihak yang sepakat bahwa abad XXI adalah peradabanpostmodernisme, maka salah satu ciri dari postmodernisme adalah semakin menguatnya spiritualisme, yang salah satu tandanya adalah dedifferentiation, yaitu agama akan menyatu kembali dengan unsur duniawi.

Berdasarkan paparan di atas, nilai-nilai humanisasi dan liberasi harus bertitik pangkal dari nilai-nilai transendensi. Kerja kemanusiaan dan kerja pembebasan harus didasarkan kepada nilai-nilai keimanan kepada Allah SWT. Nilai transendensi menghendaki umat Islam meletakkan posisi Allah SWT sebagai pemegang otoritas tertinggi. Transendensi menghendaki manusia untuk mengakui keunggulan normanorma mutlak yang melampaui akal manusia.

\section{Implementasi Pengembangan Penguatan Profesionalisme Guru PAI Berbasis Nilai- Nilai Profetik}

Pendidik adalah komponen yang sangat penting dalam sistem pendidikan, karena ia yang akan mengantarkan anak didik pada tujuan yang telah ditentukan, bersama komponen yang lain terkait dan lebih bersifat komprehensif. Al-Ghozali mempergunakan istilah pendidik dengan berbagai kata seperti, al-mulim (guru), almudarris (pengajar), al-muaddib (pendidik) dan al-walid (orang tua).

\footnotetext{
${ }^{16}$ Hassan Hanafi, Bongkar Tafsir: Liberalisasi, Revolusi, Hermeneutik (Yogyakarta: Prismasophie, 2005), 154. 
Proses pembelajaran di Prodi Pendidikan Agama Islam (PAl) pendidik (dosen) berperan besar dan strategis. Karena itu corak dan kualitas pendidikan profetik secara umum dapat diukur dengan kualitas dosen. Karena dengan dosen yang memiliki kualifikasi tinggi diharapkan dapat menciptakan dan mendesain materi yang lebih dinamis dan konstruktif, mengatasi kelemahan materi dan subjek didiknya, di antaranya dengan menciptakan suasana yang kondusif dan strategi pembelajaran aktif. Hal ini diungkapkan oleh Bapak Muhammad Thohir, Ketua Juruan Pendidikan Islam FTK UIN Sunan Ampel Surabaya:

"Dengan dosen yang memiliki kualitas tinggi, kompetensi lulusan (output) pendidikan dapat dijamin, sehingga mereka mampu mengelola potensi diri dan mengembangkan kemandirian. Singkat kata, tugas dosen ialah mengupayakan perkembangan seluruh potensi mahasiswa.."17

Berkenaan penguatan profesionalisme guru PAI, Bapak Thohir melanjutkan:

“..Dengan memperhatikan kualitas dosen, maka akan berdampak pada pengarahan terhadap mahasiswa sebagai calon guru PAl. Dosen perlu menegaskan pada mahasiswa bahwa tugas guru bukan saja bertugas mentransfer ilmu pengetahuan, tetapi juga mentransfer nilai-nilai ajaran Islam dengan semangat profetik. Guru memiliki kedudukan sangat terhormat, karena tanggungjawabnya yang berat dan mulia. Seorang guru membawa amanah Illahiyah untuk mencerdaskan mahasiswa sekaligus membawanya taat beribadah dan berakhlak mulia...."18

Berdasarkan hasil wawancara tersebut, maka syarat terpenting menjadi guru PAI adalah kepribadian. Kepribadian yang utuh meliputi tingkah laku maupun tata bahasanya. Sebab, kepribadian guru akan mudah diperhatikan dan ditiru oleh siswa, termasuk budi bahasanya.

Hal di atas, senada dengan pendapat Kuntowijoyo yang mempersyaratkan beberapa hal terkait kepribadian, secara lengkap yang harus dimiliki oleh guru, agar ia bisa menjadi pendidik yang baik, di antaranya: 1) Zuhud dan ikhlas, 2) Bersih lajir dan batin, 3) Pemaaf, sabar, dan mampu mengendalikan diri, 4) Bersifat kebapakan dan keibuan, 5) Mengenal peserta didik dengan baik (baik secara individual maupun kolektif). ${ }^{19}$

Dengan demikian, guru ideal adalah guru yang pada saat bersamaan siap menjadi mahasiswa yang baik. Sesuai dengan kedudukannya sebagai role model, seorang guru harus yang baik, shaleh, yang merasa bahwa menjadi tanggung jawabnyalah melatih para siswa agar menjadi seorang muslim yang baik, yang akan

${ }^{17}$ Muhammad Thohir, Wawancara, Surabaya, 7 Juli 2021.

18 Muhammad Thohir, Wawancara, Surabaya, 7 Juli 2021.

19 Kuntowijoyo, Muslim Tanpa Masjid (Bandung: Mizan, 2001), 105. 
menjalani kehidupan mereka sesuai dengan nilai-nilai etis, yang perbuatannya akan dijadikan teladan mahasiswa.

M. Bahri Musthofa, Sekretaris Jurusan Pendidikan Islam FTK mengatakan:

“..Dosen di Prodi PAl telah mampu mengadakan sentuhan pendidikan dengan mahasiswa dalam setiap edukasinya. Di antara dosen dan mahasiswa terjadi sentuhan pendidikan dalam kebersamaannya. Maka hal ini merupakan situasi dalam proses pendidikan. Proses tersebut berimplikasi terhadap motivasi mahasiswa untuk menjadi seorang guru yang professional sekaligus memiliki nilai-nilai luhur dan spriritualitas.."20

Sebagai pelengkap pendapat Mustofa, Arsyad menyatakan bahwa syarat-syarat menjadi guru yang baik di antaranya: menguasai bidang materi yang diajarkan, menjadi teladan dalam perkataan dan perbuatan, mampu mengimplementasikan apa yang diajarkan, memiliki keluhuran akhlak dan tingkat pendidikan, saling membantu dengan sesama guru dan senantiasa berlaku jujur. ${ }^{21}$

Itu sebabnya harus petunjuk baku dari pemerintah baik untuk pembinaan maupun penilaian kompetensi kepribadian pendidik, mengingat terpenuhinya kopetensi kepribadian dalam diri seorang dguru merupakan sesuatu yang dipersyaratkan dalam Undang-Undang. Sosok Nabi Muhammad dalam posisi sebagai guru, sebagai orang tua, ataupun sebagai anggota masyarakat saat itu merupakan suatu teladan paling ideal bagi manusia di muka bumi hingga saat ini.

Dalam konteks kepribadian pendidik, pribadi Nabi Muhammad adalah contoh terbaik, yang paling ideal dijadikan sebagai role model. Tiga dimensi profetik beserta indikator yang melekat di dalamnya dapat diintegrasikan dengan indikator kompetensi kepribadian guru sebagaimana sudah dijelaskan dalam Undang-Undang No. 14 Tahun 2015. ${ }^{22}$ Dengan demikian, akan didapatkan konstruksi pengetahuan tentang kompetensi kepribadian guru yang didasarkan pada nilai-nilai profetik yang dimiliki oleh Nabi. Guru yang dalam jiwanya telah terilhami oleh nilai-nilai transendensi akan menjalankan tugas profesionalnya dengan dasar nilai-nilai teologis. ${ }^{23}$ Dalam hal ini, Bapak Syaifuddin, salah seorang dosen mata kuliah PPL 1:

“.. Guru yang memiliki kepribadian profetik memahami bahwa tugas profesionalnya adalah bagian dari tugas kemanusiaan dari Allah. Maka tugas saya sebagai pengampu mata kuliah PPL 1 adalah memupuk kesadaran mahasiswa sebagai calon guru PAl serta menumbuhkan semangat dan keikhlasan dalam menjalankan rangkaian tugas profesional. Ketika seorang guru menyadari bahwa supervisornya bukan hanya kepala

\footnotetext{
${ }^{20}$ M. Bahri Mustofa, Wawancara, Surabaya, 14 Juli 2021.

21 Junaidi Arsyad, "Karakteristik Rosulullah Sebagai Pendidik Perspektif Sirah Nabawiyah", Jurnal Itqan, Vol. 06, No. 02 (Juli - Desember: 2015), 88.

22 Lihat, Undang-Undang No. 14 Tahun 2015.

23 Atim Rinawati,"Prophetic Teaching Sebagai Strategi Membangun Kompetensi Kepribadian Guru”, Journal Ar'rihlah: Inovasi Pengembangan Pendidikan Islam, Vol. 02, No.01 (Juni: 2018), 27.
} 
sekolah, komite sekolah atau bahkan siswa, maka setiap guru di sini akan semakin bersungguh-sungguh dalam menjalankan tanggungjawabnya.."24

Upaya yang telah maksimal dalam mencerdaskan mahasiswa tentu diikuti dengan kepasrahan total terhadap Sang Khaliq. Kesadaran bahwa yang mentransmisikan ilmu dalam pikiran anak didik bukanlah dirinya, namun Allah SWT menjadikan dpendidik yang memiliki kepribadian profetik tidak pernah lupa untuk senantiasa mendoakan anak, agar mendapatkan keberkahan ilmu.

Dalam praktik perkuliahan di kelas, Bapak M. Nawawi, salah seorang dosen senior di Prodi PAI, memberikan sebuah pandangan filosofis, sebagai berikut:

“..Meskipun kita masih menjalani perkuliahan online, dalam praktiknya, kita harus tetap memberi pemahaman dan kesadaran bahwa setiap anak didik yang sedang belajar bukanlah gelas kosong tanpa isi, akan tetapi sudah membawa potensi masing-masing yang telah dibangun oleh keluarga atau tingkat pendidikan sebelumnya. Oleh sebab itu, saya harus menegaskan ini terhadap mahasiswa, agar mereka mampu mengenali potensi anak didiknya kelak. Hal itu bertujuan untuk membantu siswa terus mengembangkan potensinya..."25

Lebih lanjut, Bapak Nawawi mengatakan:

“..Ilmu pengetahuan dan pendidikan merupakan unsur yang sangat berpengaruh terhadap kehidupan siswa, di antaranya adalah pengembangan potensi, motivasi dan tentunya aktualisasi diri. Kita dapat menuangkan tidak hanya ketika kita mengajar, tetapi juga ketika mahasiswa berkonsultasi secara pribadi."26

Seorang yang berilmu diharapkan akan mampu membawa dirinya maupun orangorang di sekitarnya terhadap kualitas kehidupan yang lebih baik. Maka, seorang guru perlu memiliki semangat yang kuat sebagai penggerak transformasi sosial. Motivasi juga diperlukan untuk meningkatkan kualitas hidup masyarakat khususnya anak didik. Dalam hal ini, Roqib berargumen bahwa pendidik yang humanis merupakan salah satu indikator dimilikinya kepribadian profetik. ${ }^{27}$

Dalam sebuah kesempatan, penulis mewawancarai Muhammad Fahmi, sekretaris Prodi PAl, via telfon. la menegaskan bahwa semua dosen di Prodi PAl (dengan beragam mata kuliah yang diampu) telah diinstruksikan agar memberi arahan dan bimbingan terhadap mahasiswa terkait profesionalisme seorang pendidik. Agar ketika mahasiswa terjun langsung menjadi seorang guru, mereka dapat menjalankan tugas profesionalnya dengan baik berdasarkan nilai-nilai profetik. Berikut pemaparannya:

\footnotetext{
24 Syaifuddin, Wawancara, Surabaya, 6 Agustus 2021.

${ }^{25}$ M. Nawawi, Wawancara, Surabaya, 19 Agustus 2021

${ }^{26}$ M. Nawawi, Wawancara, Surabaya, 19 Agustus 2021.

27 Moh. Roqib, Prophetic Education (Purwokerto: STAIN Press, 2011), 79.
} 
“.. Para dosen di Prodi PAl sudah kami instruksikan agar mengarahkan mahasiswa dan memberi pemahman terkait kompetensi professional seorang guru. Misalnya dengan menjaga nilai-nilai kemanusiaan. Para dosen harus menghargai mahasiswa secara total baik fisik maupun psikis, juga perbedaan latar belakang sosial. Para dosen memegang teguh nilai-nilai humanisme, mereka mampu membuat siswa merasa dihargai dan dihormati. Dengan begitu, mahasiswa akan menjadikan pemahamn tersebut sebagai acuan saat mereka menjadi sorang guru, sehingga mampu menciptakan suasana pembelajaran yang nyaman...."28

Berdasarkan pendapat Bapak Fahmi di atas, maka dengan pengembangan profesionalisme melalui nilai-nilai profetik menjadikan tujuan pembelajaran lebih mudah untuk diraih, serta kualitas pendidikan akan terjaga. Mengintegrasikan nilai-nilai profetik dalam membuat acuan penilaian kompetensi kepribadian mahasiswa PAI bukanlah hal yang mudah. Harus dipahami terlebih dahulu esesensi dari pardigma profetik. Indikator-indikator yang melekat pada tiga dimensi profetik yaitu transendensi, liberasi, dan humanisasi.

Tahap berikutnya adalah mengintegrasikan nilai-nilai tersebut dengan indikator kompetensi kepribadian yang sudah dijabarkan pemerintah sebagaimana tercantum dalam Undang-Undang. Tentu saja pembentukan kepribadian seorang calon guru harus menjadi agenda yang benar-benar dipersiapkan oleh lembaga seperti dilakukannya pembinaan kepribadian. Kompetensi profesionalisme sebagaimana diamanatkan oleh Undang-Undang adalah guru harus memiliki kepribadian yang mantap, stabil, dewasa, arif, berwibawa, menjadi teladan bagi peserta didik, serta berakhlak mulia. ${ }^{29}$ Pemenuhan kompetensi profesionalisme berbasis nilai-nilai profetik menjadi sangat penting terlebih bagi seorang guru PAI yang menjadi subjek teramati oleh anak didik.

Temuan di atas selaras dengan penelitian yang dilakukan oleh Hebert dan Breadley, bahwa kepribadian seseorang akan berpengaruh terhadap profesionalisme dan kinerja. ${ }^{30} \mathrm{Hal}$ inilah yang mendorong Prodi Pai FTK UIN Sunan Ampel Surabaya melakukan upaya-upaya pengembangan kepribadian sekaligus pengembangan profesionalisme guru terhadap mahasiswa PAI. Karena dengan kepribadian baik, seorang guru akan memiliki profesionalisme kerja dan loyalitas yang baik pula. Seorang guru yang memiliki kepribadian baik akan menyadari tugas, kewajibannya, tanggung jawab serta memiliki motivasi yang tinggi untuk terus memperbaiki kualitas proses belajar mengajar dalam posisinya sebagai pendidik.

\footnotetext{
${ }^{28}$ Muhammad Fahmi, Wawancara, Surabaya, 1 September2021.

${ }^{29}$ Kuntowijoyo, Muslim Tanpa Masjid (Bandung: Mizan, 2001), 98.

30 J.H. Breadley, Hebert , "The Effect of Personality Type on Team Performance", Journal of Managemen Development, Vol. 16, No. 337-353 (1997).
} 
Sebagai bagian dari profesionalisme, penggunaan metode pembelajaran menjadi hal yang tidak dapat dikesampingkan. Dosen diharuskan menerapkan prosedur umum dalam penyampaian materi untuk mencapai tujuan pendidikan didasarkan atas asumsi tertentu tentang hakikat nilai-nilai profetik sebagai suprasistem. ${ }^{31}$

“..Dalam proses perkuliahan, metode mempunyai kedudukan yang sangat penting dalam upaya pencapaian tujuan, karena ia menjadi sarana dalam menyampaikan materi perkuliahan yang tersusun dalam kurikulum Prodi PAl. Metode yang tepat guna apabila mengandung nilai-nilai yang intrinsik dan ekstriksik sejalan dengan materi pelajaran dan secara fungsional dapat dipakai untuk merealisasikan nilai-nilai ideal yang terkandung dalam tujuan pendidikan Islam.."32

Ada tiga aspek nilai yang terkandung dalam tujuan pendidikan Islam yang hendak direalisasikan melalui metode yang mengandung watak dan relevansi tersebut: 1) Membentuk karakter mahasiswa, 2) Bernilai edukatif yang mengacu kepada petunjuk al Qur'an, 3) Berkaitan dengan motivasi dan kedisiplinan. Dalam hubungannya dengan watak dan relevansinya, ketiga aspek tersebut merupakan dasar timbulnya pola pemikiran model-model proses belajar mengajar di Prodi PAl.

Secara esensial, dalam penguatan profesionalisme guru harus mengakui kebenaran adanya fitrah sebagai kemampuan dasar yang dikaruniakan Allah dalam tiap diri manusia. Keyakinan tentang potensi fitrah tersebut telah dijadikan para dosen di Prodi PAl untuk mendorong mahasiswa sebagai calon guru PAI untuk berikhtiar sebaik mungkin dengan pemilihan metode-metode kependidikan efektif dan efisien. Pada saat yang sama, para dosen mendorong mahasswa untuk berikhtiar menghindarkan pengaruh-pengaruh negatif terhadap perkembangan fitrah melalui program-program kegiatan kependidikan yang berarah pada tujuan dan substansi pendidikan Islam

“..Kami mengupayakan harmonisasi, keserasian, dan keselarasan antara masukan instrumental dengan masukan environmental (pengaruh lingkungan) dalam proses mancapai tujuan, sehingga produk pendidikan benar-benar sesuai dengan idealitas Islami. Kami juga mengusahakan terciptanya model-model proses belajar mengajar yang bersifat fleksibel terhadap tuntutan kebutuhan hidup anak didik. Di sisi lain, kami senantiasa berpegang teguh pada pola pengembangan hidup mahasiswa yang berorientasi pda potensi keimanan dan ilmu pengetahuan yang dapat menopang profesionalisme calon guru PAI..." ${ }^{33}$

Dengan mata kuliah metode pembelajaran, mahasiswa diajarkan cara atau kepandaian membuat atau melakukan sesuatu yang digunakan untuk mengajar (atau menguji) suatu kemahiran atau aspek dalam wujud aktivitas, strategi atau taktik dan

\footnotetext{
${ }^{31}$ Moh. Roqib, Prophetic Education (Purwokerto: STAIN Press, 2011), 138.

32 Muhammad Fahmi, Wawancara, Surabaya, 19 September2021.

${ }^{33}$ M. Bahri Mustofa, Wawancara, Surabaya, 4 September 2021.
} 
bahan atau alat yang terkait dengan pendukungnya. ${ }^{34}$ Mata kuliah tersebut merupakan materi tentang cara operasional yang diterapkan oleh pendidik dalam proses pembelajaran, misalnya pembelajaran aktif dengan metode diskusi, resitasi, problem solving, demonstrasi dan lain sebagainya. Dengan menyisipkan nilai-nilai profetik, maka langkah-langkah kongkret pada waktu seorang pendidik melaksanakan pendidikan di kelas akan berjalan dengan baik.

“..Dengan mata kuliah metode pembelajaran PAl, maka penjabaran dari asumsi-asumsi dasar dari pendekatan dan nilai-nilai profetik dapat ditransmisikan secara efektif. Tujuan mata kuliah metode pembelajaran PAl adalah menjadikan mahasiswa sebagai calon guru PAl dapat memahami proses dan hasil belajar mengajar yang berdayaguna.." 35

Metode pembelajaran yang efektif dan kontekstual, dapat menimbulkan kesadaran peserta didik untuk mengamalkan ajaran Islam melalui teknik motivasi yang meningkatkan motivasi belajar peserta didik secara bertahap, sehingga proses pembelajaran menjadi efektif dan efisien.

Penguatan profesionalisme guru PAI berbasis nilai-nilai profetik pada mahasiswa prodi PAl di Fakultas Tarbiyah dan Keguruan UIN Sunan Ampel Surabaya juga diimplementasikan dengan mengadakan aplikasi prinsip-prinsip psikologis dan pedagogis sebagai kegiatan antar hubungan pendidikan dan terealisasinya melalui penyampaian keterangan dan pengetahuan. Agar mahasiswa mengetahui, memahami, menghayati dan meyakini materi serta meningkatkan keterampilan olah pikir dan membuat perubahan dalam sikap dan minat serta memenuhi nilai dan norma. Hal-hal yang penting untuk diperhatikan sebagai dasar penggunaan implementasi pengembangan penguatan profesionalisme guru PAI berbasis nilai-nilai profetik pada mahasiswa prodi PAI .

Pada dasarnya implementasi penguatan profesionalisme guru PAI berbasis nilainilai profetik bertumpu pada nilai spiritual dan mental yang menyertai pada saat hal tersebut tersebut dilaksanakan atau dipraktekkan. Prinsip dasar implementasinya antara lain: 1) Niat dan orientasinya untuk mendekatkan hubungan antara manusia dengan Allah dan sesama makhluk; 2) Keterpaduan (integrative); 3) Bertumpu pada tauhid; 4) Kejujuran; 5) Keteladanan pendidik. Ada kesatuan ilmu dan amal; 6) Berdasar pada nilai dan tetap berdasarkan pada alakhlaq al-karimah, budi utama) Sesuai dengan usia dan kemampuan akal anak; 7) Sesuai dengan kebutuhan peserta

\footnotetext{
${ }^{34}$ Hasil observasi penulis di Prodi PAI Fakultas Tarbiyah dan Keguruan UIN Sunan Ampel Surabaya.

${ }^{35}$ Muhammad Fahmi, Wawancara, Surabaya, 19 September2021.
} 
didik; 8) Mengambil pelajaran pada setiap kasus atau kejadian; 9) Proporsional dalam memberikan janji yang menggembirakan dan ancaman untuk mendidik kedisiplinan.

Pengembangan penguatan profesionalisme guru PAI berbasis nilai-nilai profetik juga dapat menggunakan metode yang disebut dengan edutainment atau pendidikan yang menyenangkan dengan tanpa meninggalkan hukuman jika dibutuhkan. ${ }^{36}$ Edutainment dalam pandangan Rosyadi merupakan pembelajaran yang memberikan kesempatan kepada peserta didik untuk terlibat dan menikmati proses pembelajaran dalam suasana yang kondusif dengan proses pembelajaran yang rileks, menyenangkan dan bebas dari tekanan baik fisik maupun psikis. ${ }^{37}$

Pengembangan penguatan profesionalisme guru PAI berbasis nilai-nilai profetik dipilih dan dilakasanakan oleh para dosen secara transenden dibarengi dengan rasa tulus ikhlas, sehingga mahasiswa sebagai calon guru PAl tergugah semangat dan gerak edukatifnya dengan rasa senang dan nyaman. Yang paling penting adalah mahasiswa dapat merefleksi apa yang dilaksanakan dosen. Sehingga saat mereka menjadi seorang guru hal tersebut dapat diimplementasikan dengan baik dan benar. Siraman nilai spiritual yang berdimensi liberasi dan humanisme akan memberikan sentuhan yang kuat untuk berbuat demi kemanfaatan ilmu pengetahuan di tengah masyarakat dan lingkungannya.

\section{Problematika dalam Implementasi Pengembangan Penguatan Profesionalisme Guru}

\section{PAI berbasis Nilai-Nilai Profetik}

Setiap proses tidak selalu berjalan baik. Adakalanya sebuah proses terdapat hambatan yang mengirinya. Demikian pula dengan problematika yang muncul dalam implementasi pengembangan penguatan profesionalisme guru PAI berbasis nilai-nilai profetik pada mahasiswa prodi PAI Fakultas Tarbiyah dan Keguruan UIN Sunan Ampel Surabaya. Meski dilaksanakan secara optimal, ada beberapa problem dalam proses implementasinya, antara lain:

1. Latar belakang keilmuan dosen

Meski telah diadakan pertemuan dosen-dosen PAI untuk mengimplentasikan pengembangan penguatan profesionalisme guru PAI berbasis nilai-nilai profetik pada mahasiswa prodi PAl, tidak dapat dipungkiri latar belakang keilmuan dosen pengampu mata kuliah berdampak pada terhambatnya proses tersebut. Hal ini disampaikan oleh Bapak Muhammad Fahmi, selaku Sekretaris Prodi PAl, berikut ini:

\footnotetext{
${ }^{36}$ Hasil observasi penulis di Prodi PAI Fakultas Tarbiyah dan Keguruan UIN Sunan Ampel Surabaya.

37 Khoiron Rosyadi, Pendidikan Profetik (Yogyakarta: Pustaka Pelajar, 2004), 143.
} 
“.. Sebenarnya kami sudah melakukan komunikasi, koordinasi dan pertemuan (offline dan online). Namun perbedaan latar belakang keilmuan dosen juga berpengaruh terhadap implementasi pengembangan penguatan profesionalisme guru PAl berbasis nilai-nilai profetik pada mahasiswa prodi PAl. Misalnya dosen yang mengampu mata kuliah dasar umum akan sulit memahami desain implementasinya dan juga berdampak pada proses pemahaman mahasiswa.."38

Senada dengan Bapak Fahmi, Bapak Muhammad Thohir menyatakan hal berikut ini:

“..Ya itu wajar. Karena latar belakang keilmuan merupakan passion masing-masing dosen. Tentu hal tersebut membuat pengetahuan dan pemahaman dosen yang bersangkutan terkait pengembangan penguatan profesionalisme guru PAI berbasis nilai-nilai profetik juga kurang. Tapi hal itu dapat kita atasi dengan koordinasi antar dosen.."39

Dari dua pendapat di atas, dapat dipahami bahwa tidak semua dosen dapat mengimplementasikan pengembangan penguatan profesionalisme guru PAl berbasis nilai-nilai profetik pada mahasiswa prodi PAl sesuai rencana yang ditetapkan. Namun demikian, Prodi PAI membuka dialog dan koordinasi dengan dosen yang mempunyai latar belakang keilmuan pedagogis yang kuat.

2. Pemahaman mahasiswa terhadapdesain pembelajaran

Problem kedua adalah pemahaman mahasiswa terhadap desain pembelajaran. Faktor yang menjadi penghambat untuk meningkatkan profesional seperti kurangnya memahami isi dari kurikulum yang ditetapkan. Kongkritnya, mahasiswa tidak memahami desain perkuliahan dosen, seperti Rencana Pembelajaran Semester. ${ }^{40}$ Sehingga berdampak pada pemahaman terkait penguatan profesionalisme guru PAI berbasis nilai-nilai profetik yang diterapkan.

Pemahaman terhadap desain dan perencanaan pembelajaran menjadi penting untuk diketahui sebagai calon pendidik. Desain dan perencanaan pembelajaran memiliki fungsi yang beragam yang kesemuanya bermuara pada tujuan yang sama yaitu agar tujuan pembelajaran dapat tercapai dengan efektif dan efisisen sehingga output yang dihasilkan pun memiliki kualitas yang tidak diragukan.

3. Sarana Pendukung

Fakultas Tarbiyah memili tiga Gedung yang digunakan untuk operasional atau pelaksanaan perkuliahan: Gedung A, Gedung E1 dan Gedung Eltis. Untuk Gedung A,

\footnotetext{
38 Muhammad Fahmi, Wawancara, Surabaya, 19 September2021.

39 Muhammad Thohir, Wawancara, Surabaya, 15 Juli 2021.

40 Hasil observasi penulis di Prodi PAI Fakultas Tarbiyah dan Keguruan UIN Sunan Ampel Surabaya.
} 
fasilitas lengkap dan baru. Selain itu, jaringan internet juga kuat. Sehingga dalam proses pengembangan penguatan profesionalisme guru PAl berbasis nilai-nilai profetik pada mahasiswa prodi PAI Fakultas Tarbiyah dan Keguruan UIN Sunan Ampel Surabaya dapat memfungsikan fasilitas yang ada secara efektif. Namun, fasilitas di Gedung E1 dan Gedung Eltis masih kurang mendukung. Jaringan internet juga terbatas. Hal inilah yang menjadi problem signifikan dalam implementasi pengembangan penguatan profesionalisme guru PAI berbasis nilai-nilai profetik pada mahasiswa prodi PAI Fakultas Tarbiyah dan Keguruan.

“..Memang harus diakui fasilitas berpengaruh terhadap implementasi pengembangan penguatan profesionalisme guru PAl berbasis nilai-nilai profetik pada mahasiswa prodi PAI Fakultas Tarbiyah dan Keguruan. WiFi misalnya. Jaringan internet sangat terbatas pada Gedung E1 dan Gedung Eltis. Kami para dosen sulit mendapat informasi baru yang berbasis internet sebagai bahan ajar.." 41

Pendapat di atas selaras dengan argument Bafadal, yang menyatakan bahwa sarana dan prasarana pendidikan merupakan elemen atau komponen yang penting yaitu fasilitas untuk keberhasilan dan kelancaran dalam memberikan kemudahan di lingkup pendidikan. Terutama sangat diperlukan dalam mendukung proses pembelajaran. ${ }^{42}$

Fasilitas memang bagian penting dari sebuah proses pendidikan, apapun bentuk dan tingkatannya. Sehingga pihak pimpinan Fakultas Tarbiyah dan Keguruan perlu membenahi beberapa problem tersebut, agar implementasi pengembangan penguatan profesionalisme guru PAI berbasis nilai-nilai profetik pada mahasiswa prodi PAl Fakultas Tarbiyah dan Keguruan UIN Sunan Ampel Surabaya berjalan dengan efektif dan efisien.

\section{E. Dampak Implementasi Pengembangan Penguatan Profesionalisme Guru PAI berbasis Nilai-Nilai Profetik}

Nilai-nilai profetik mengarah pada tiga aspek, yaitu humanisasi atau menyuruh kepada kebaikan (amar ma'ruf), liberasi atau mencegah kejahatan (nahi munkar), dan transendensi atau beriman kepada Tuhan (tu' minu billah). Tiga tersbut merupakan bagian dari tugas dan kewajiban guru dalam mendidik para siswanya. Dalam implementasi pengembangan penguatan profesionalisme guru PAI berbasis nilai-nilai profetik pada mahasiswa prodi PAI Fakultas Tarbiyah dan Keguruan UIN Sunan Ampel

\footnotetext{
${ }^{41}$ M. Nawawi, Wawancara, Surabaya, 19 Agustus 2021.

42 Lihat, Ibrahim Bafadal, Manajemen Perlengkapan Sekolah Teori dan Aplikasinya (Jakarta: Bumi Aksara, 2008).
} 
Surabaya mahasiswa harus selalu menanamkan nilai-nilai humanisme, seperti toleransi, menhargai hak-hak orang lain, dan menghargai keberagaman. Jika semangat ini disadari betul oleh mahasiswa sebagai calon guru, maka dapat mereduksi bahkan dapat mencegah dehumanisasi pada masa yang akan datang.

Setelah pengembangan penguatan profesionalisme guru PAI berbasis nilai-nilai profetik pada mahasiswa prodi PAI Fakultas Tarbiyah dan Keguruan diimplementasikan, ada beberapa dampak atau hasil yang menyertainya. Berdasarkan temuan penulis, dampak atau hasil dari implementasi proses tersebut di antaranya:

1. Menciptakan suasana pembelajaran yang menyenangkan

Menurut Bapak Thohir, penguatan profesionalisme guru PAl berbasis nilainilai profetik pada mahasiswa prodi PAI Fakultas Tarbiyah dan Keguruan melibatkan metode yang positif dan sesuai dengan kondisi peserta didik. Bagaimana pendidikan dapar memberikan peluang bagi peserta didik untuk "gandrung ilmu" dan terus mengulang proses pencarian ilmu karena metode yang dilakukan oleh pendidik begitu menarik dan menyenangkan. ${ }^{43}$

Pendidikan profetik yang menyenangkan adalah pembelajaran yang memberi kesempatan kepada peserta didik untuk terlibat dan menikmati proses pembelajaran dalam suasana yang kondusif dengan pembelajaran yang menyenangkan dan tidak memberikan tekanan fisik maupun psikis. Manfaat penggunaan desain pembelajaran yang berbasis edutainment Plus adalah: ${ }^{44}$ 1) Membuat peserta didik gembira dan membuat belajar menjadi terasa lebih mudah, 2) Mendesain pembelajaran dengan selipan humor dan permainan edukatif untuk memperkuat pemahaman materi, 3) Komunikasi menjadi efektif dan penuh dengan keakraban, 4) Penyampaian materi pelajaran pada yang dibutuhkan dan bermanfaatkan, 5) Penyampaian materi sesuai dengan kemampuan peserta didik, 6) Memberikan reward dan hadiah sebagai motivasi untuk peserta didik, 7) Pemberian sanksi atau hukuman secara edukatif dan proporsional jika diperlukan untuk memantapkan kedisiplinan peserta didik, 8) Penerapan edutainment puls dalam perspektif profetik, sekali lagi tetap tidak meninggalkan sama sekali terhadap hukuman jika diperlukan untuk mendisiplinkan peserta didik.

2. Mengembangkan aspek kebudayaan peserta didik

Penguatan profesionalisme guru PAl berbasis nilai-nilai profetik pada mahasiswa prodi PAI Fakultas Tarbiyah dan Keguruan dapat mengembangkan aspek

\footnotetext{
${ }^{43}$ Muhammad Thohir, Wawancara, Surabaya, 3 Oktober 2021.

${ }^{44}$ Hasil observasi penulis di Prodi PAI Fakultas Tarbiyah dan Keguruan UIN Sunan Ampel Surabaya. 
kebudayaan yang digerakkan melalui penguatan pada aspek-aspek subjektif atau objektif budaya. Penguatan dilakukan dengan memberikan stimulasi. Setelah lebih jelas tentang format dan desain pendidikan profetik dengan mengenalkan tradisi dan dan mengembangkan budaya. ${ }^{45}$ Diharapkan konsep pendidikan ini mampu mengilhami perkembangan pola pendidikan baru sebagai alternatif.

3. Membentuk karakter calon guru ideal

Penguatan profesionalisme guru PAl berbasis nilai-nilai profetik pada mahasiswa prodi PAl Fakultas Tarbiyah dan Keguruan dapat diartikulasikan dan aktualisasikan dalam praktik pengembangan pendidikan Islam.

“..Sebagaimana telah kita ketahui, bahwa pendidikan profetik dengan dasar tradisi dilakukan dengan pilar transendensi, humanisasi dan liberalisasi secara otomatis membangun karakter guru ideal. Guru ideal adalah figur yang dinamis yang bergerak sesuai dengan orientasi dan visi yang jelas di bawah kepemimpinan yang bijaksana..." 46

Guru ideal yang diikuti tiga kata dibelangkangnya yaitu amar ma'ruf (humanisasi), nahi mungkar (liberasi) dan iman kepada Allah (transendensi). Jika dikaitkan dengan hal tersebut maka pendidikan profetik harus dibangun berdasarkan empat syarat dan tiga pilar, yaitu komunitas, visi, gerak dinamis dan kepemimpinan.

4. Aktualisasi pendidikan multikultural

Sebagaimana yang banyak disebutkan, pernyataan "orang miskin dilarang sekolah" atau "orang miskin dilarang sakit" merupakan identitas sosial yang harus segera digeser dan dirubah dengan pendidikan profetik. Pendidikan profetik dalam artian ini adalah pendidikan kerakyatan. Agar program ini faktual dan aktual maka program pendidikan yang dilakukan harus memanfaatkan potensi lokal. ${ }^{47}$

“..Penguatan profesionalisme guru PAI berbasis nilai-nilai profetik pada mahasiswa prodi PAl berdampak pada inklusifitas pemikiran mahasiswa. Dari pemikiran inklusif tersebut tumbuh benih multikulturalisme. Pendidikan multikultural dikembangkan dengan pemanfaatan potensi seni dan budaya lokal..." 48

Dari pendapat di atas, dapat dipahami bahwa Islam harus dihayati sampai kepada makna dan ruhnya. Penghayatan sampai makna seperti ini menuntu sebuah perombakan kurikulum dalam pendidikan. Sebab, pendidikan yang berhasi mencapai

\footnotetext{
45 Hasil observasi penulis di Prodi PAI Fakultas Tarbiyah dan Keguruan UIN Sunan Ampel Surabaya.

46 Muhammad Fahmi, Wawancara, Surabaya, 19 September2021.

47 Dwi Priyanto, Pendidikan Berbasis Nilai-Nilai Profetik Di Madrasah Ibtidaiyah (Banyumas: CV. Rizquna, 2021), 88.

${ }^{48}$ M. Bahri Mustofa, Wawancara, Surabaya, 4 September 2021.
} 
tujuan diantaranya adalah menghasilkan lulusan yang mampu menghargai keberbadaan dan keragaman kultur (multikultural).

Pendidikan multikultural dikembangkan untuk menjawab kegelisahan terhadap pemahaman mengenai pluralitas yang sempit. Kaitanya dengan soal pluralisme, penting untuk digarisbawahi bahwa multikuturalisme itu berbeda dengan pluralisme. Pluralisme hanya sebuah pengakuan terhadap keberagaman tentang kemajemukan atau kebhinekaan.

Pendidikan multikultural berfungsi sebagai pemahaman terhadap proses pendidikan yang menentang bentuk diskriminasi di sekolah dan masyarakat bisa diterapkan oleh peserta didik, komunitas mereka dan para pendidik. Fokus dari pendidikan multikultural adalah pada kecerdasan siswa yang menguasai ilmu dan menyelesaikan masalah, tetapi dengan dasar moral yang menghargai diri sendiri dan orang lain dari berbagai latar belakang yang berbeda. Pendidikan multikultural dalam penguatan profesionalisme guru PAl berbasis nilai-nilai profetik pada mahasiswa prodi PAl menempatkan dasar transendensi, humanisasi dan liberasi untuk menjadi pilar yang mencerminkan adanya kebersatuan dan kesamaan secara teologis di hadapan Tuhan, saling menghargai sebagai sesama manusia dan saling membangun kebersamaan dalam menegakkan keadilan melawan diskriminasi dalam bentuk apapun.

5. Mahasiswa terlatih melaksanakan pembelajaran integratif

Kebutuhan hidup manusia amat banyak dan beragam. Pengetahuan saja tidak cukup untuk membuat hidup manusia menjadi tentram dan bahagia. Pemahaman akan hukum alam, sosial dan teologis memerlukan paket materi pelajaran yang holistik dan komprehensif. Menurut Roqib, krisis kearifan dalam pendidikan dia ntaranya karena perlakuan lembaga pendidikan tidak tepat terhadap ilmu pengetahuan. ${ }^{49}$

Pendidikan intregratif merupakan bagian dari pengembangan penguatan profesionalisme guru PAI berbasis nilai-nilai profetik pada mahasiswa prodi PAI FTK UIN Sunan Ampel. Artinya penguatan profesionalisme guru PAl berbasis nilai-nilai profetik sulit berjalan dengan baik tanpa membangun pendidikan yang integratif. ${ }^{50}$ Integratif dalam teori, desain, sistem, pelaksanaan dan integratif dalam kelembagaan. Integratif dalam arti jejaring antar lembaga adalah berwujud kerjasama untuk melaksanakan program bersama untuk menyiapkan media

\footnotetext{
49 Roqib, Ilmu Pendidikan Islam, 149.

50 M. Nawawi, Wawancara, Surabaya, 4 Oktober 2021. 
pendidikan dan pelayanan prima tanpa pembebanan pada peserta didik secara sosial dan ekonomi. Dari aspek kelembagaan, penguatan profesionalisme guru PAI berbasis nilai-nilai profetik adalah mengintegrasikan ilmu (kurikulum), kebijakan dan kelembagaannya.

\section{F. Kesimpulan}

Berdasarkan temuan, uraian dan analisis pada bagian sebelumnya, maka penulis menyimpulkan penelitian ini sebagai berikut: Pertama, dengan mengimplementasikan pengembangan profesionalisme melalui nilai-nilai profetik menjadikan tujuan pembelajaran lebih mudah untuk diraih, serta kualitas pendidikan akan terjaga. Mengintegrasikan nilai-nilai profetik harus dipahami terlebih dahulu esesensi dari pardigma profetik. Tahap berikutnya adalah mengintegrasikan nilai-nilai tersebut dengan indikator kompetensi kepribadian yang sudah dijabarkan pemerintah sebagaimana tercantum dalam Undang-Undang. Tentu saja pembentukan kepribadian seorang calon guru harus menjadi agenda yang benar-benar dipersiapkan oleh lembaga seperti dilakukannya pembinaan kepribadian. Kedua, dalam proses implementasi program tersebut muncul beberapa problem yang menjadi penghambat. Meski dilaksanakan secara optimal, ada beberapa problem di antaranya: 1) Latar belakang keilmuan dosen; 2) Pemahaman mahasiswa terhadapdesain pembelajaran; 3) Sarana pendukung. Latar belakang keilmuan, pemahaman mahasiswa, dan fasilitas memang bagian penting dari sebuah proses pendidikan, apapun bentuk dan tingkatannya. Sehingga pihak pimpinan Fakultas Tarbiyah dan Keguruan perlu membenahi beberapa problem tersebut, agar implementasi pengembangan penguatan profesionalisme guru PAI berbasis nilai-nilai profetik pada mahasiswa prodi PAl Fakultas Tarbiyah dan Keguruan UIN Sunan Ampel Surabaya berjalan dengan efektif dan efisien. Ketiga, setelah program tersebut diimplementasikan, ada beberapa dampak yang menyertainya di antaranya: 1) Menciptakan suasana pembelajaran yang menyenangkan; 2) Mengembangkan aspek kebudayaan peserta didik; 3) Membentuk karakter calon guru ideal; 4) Aktualisasi pendidikan multicultural; 5) Mahasiswa terlatih melaksanakan pembelajaran integrative. pengembangan penguatan profesionalisme guru PAI berbasis nilai-nilai profetik pada mahasiswa prodi PAI Fakultas Tarbiyah dan Keguruan UIN Sunan Ampel Surabaya mahasiswa harus selalu menanamkan nilai-nilai humanisme, seperti toleransi, menhargai hak-hak orang lain, dan menghargai keberagaman. Jika semangat 
ini disadari betul oleh mahasiswa sebagai calon guru, maka dapat mereduksi bahkan dapat mencegah dehumanisasi pada masa yang akan datang.

\section{G. Referensi}

Apandi, Idris. Guru Profesional Bukan Guru Abal - Abal. Yogyakarta : Deepublish, 2017.

Arsyad, Junaidi. "Karakteristik Rosulullah Sebagai Pendidik Perspektif Sirah Nabawiyah", Jurnal Itqan, Vol. 06, No. 02 (Juli - Desember: 2015).

Bafadal, Ibrahim. Manajemen Perlengkapan Sekolah Teori dan Aplikasinya. Jakarta: Bumi Aksara, 2008.

Breadley, J.H. \& Hebert. "The Effect of Personality Type on Team Performance", Journal of Managemen Development, Vol. 16, No. 337-353 (1997).

Hanafi, Hassan. Bongkar Tafsir: Liberalisasi, Revolusi, Hermeneutik. Yogyakarta: Prismasophie, 2005.

Kaswardi, EM. Pendidikan Nilai Memasuki Tahun 2000. Jakarta: Gramedia, 2001.

Kuntowijoyo. Islam Sebagai Ilmu: Epistemologi, Metodologi, dan Etika. Yogyakarta: Tiara Wacana, 2006.

Kuntowijoyo. Islam Sebagai Ilmu: Epistemologi, Metodologi, dan Etika. Yogyakarta: Tiara Wacana, 2006.

Kuntowijoyo. Muslim Tanpa Masjid. Bandung: Mizan, 2001.

Kuntowijoyo. Paradigma Islam Interpretasi Untuk Aksi. Bandung: Mizan, 1998.

Majid, Abdul., dan Andayani, Dian. Pendidikan Agama Islam Berbasis Kompetensi. Bandung: Remaja Rosda Karya, 2004.

Muhajir, Noeng. Metodologi Penelitian Kualitatif. Yogyakarta: Rake Sarasin, 2000.

Priyanto, Dwi. Pendidikan Berbasis Nilai-Nilai Profetik Di Madrasah Ibtidaiyah. Banyumas: CV. Rizquna, 2021.

Rasyadi, Khoiron. Pendidikan Profetik. Yogyakarta: Pustaka Pelajar, 2004.

Rembangy, Musthofa. Pendidikan Transformatif Pergulatan Kritis Merumuskan Pendidikan Di Tengah Pusaran Arus Globalisasi. Yogyakarta: TERAS, 2010.

Rinawati, Atim."Prophetic Teaching Sebagai Strategi Membangun Kompetensi Kepribadian Guru", Journal Ar'rihlah: Inovasi Pengembangan Pendidikan Islam, Vol. 02, No.01 (Juni: 2018).

Roqib, Moh. Prophetic Education Kontekstualisasi Filsafat dan Budaya Profetik Dalam Pendidikan. Porwokerto: Sains Press, 2007.

Rouf, Abd. "Potret Pendidikan Agama Islam di Sekolah Umum”. Jurnal Pendidikan Agama Islam (Journal of Islamic Education Studies), Vol.3 No.1 (2016): 187-206. 
Sakir, Moh. "Pendidikan Islam dalam Sistem Pendidikan Nasional”. Cendekia, Vol. 12 No. 1 (Juni 2014).

Sari, C.P. ., Zainiyati, H. S. \& Hana, R. A. “Buliding Students' Character Through Prophetic Education at Madrasa", Jurnal Pendidikan Islam, Vol. 6 No. 1 (June 2020).

Tim Penyusun. Panduan Penyelenggaraan Pendidikan Program Strata Satu Tahun 2016. Surabaya: UINSA Press, 2016.

Tim Redaksi. Kamus Besar Bahasa Indonesia Pusat Bahasa. Jakarta: PT. Gramedia, 2008.

Undang-Undang No. 14 Tahun 2015.

\section{Hasil Wawancara}

Muhammad Thohir, Wawancara, Surabaya, 7 Juli 2021.

M. Bahri Mustofa, Wawancara, Surabaya, 14 Juli 2021.

Syaifuddin, Wawancara, Surabaya, 6 Agustus 2021.

Muhammad Fahmi, Wawancara, Surabaya, 1 September2021.

M. Nawawi, Wawancara, Surabaya, 4 Oktober 2021. 